\title{
Correction to: Immunogenicity of Biosimilars for Rheumatic Diseases, Plaque Psoriasis, and Inflammatory Bowel Disease: A Review from Clinical Trials and Regulatory Documents
}

\author{
Vibeke Strand $^{1}$ D . Joao Gonçalves ${ }^{2} \cdot$ Timothy P. Hickling $^{3} \cdot$ Heather E. Jones $^{4} \cdot$ Lisa Marshall $^{4} \cdot$ John D. Isaacs $^{5}$
}

Published online: 26 February 2020

(c) The Author(s) 2020

\section{Correction to: BioDrugs (2020) 34:27-37 https://doi.org/10.1007/s40259-019-00394-x}

The article Immunogenicity of Biosimilars for Rheumatic Diseases, Plaque Psoriasis, and Inflammatory Bowel Disease: A Review from Clinical Trials and Regulatory Documents, written by Vibeke Strand, Joao Gonçalves, Timothy P. Hickling, Heather E. Jones, Lisa Marshall and John D. Isaacs, was originally published Online First without Open Access. After publication in volume 34, issue 1, pages 27-37 the author decided to opt for Open Choice and to make the article an Open Access publication. Therefore, the copyright of the article has been changed to (C) The Author(s) 2020 and the article is forthwith distributed under the terms of a Creative Commons Attribution-NonCommercial 4.0 International License (https://creativecommons.org/licenses/ by-nc/4.0/), which permits any non-commercial use, sharing, adaptation, distribution and reproduction in any medium or format, as long as you give appropriate credit to the original author(s) and the source, provide a link to the Creative Commons licence, and indicate if changes were made.

The original article can be found online at https://doi.org/10.1007/ s40259-019-00394-x.

Vibeke Strand

vibekestrand@me.com

1 Division of Immunology/Rheumatology, Stanford University School of Medicine, 306 Ramona Road, Portola Valley, Palo Alto, CA 94028, USA

2 iMed-Research Institute for Medicines, Faculdade de Farmácia da, Universidade de Lisboa, Lisbon, Portugal

3 Biomedicine Design, Pfizer, Andover, MA, USA

4 Inflammation and Immunology, Pfizer, Collegeville, PA, USA

5 Institute of Cellular Medicine, Newcastle University and Musculoskeletal Unit, Newcastle upon Tyne Hospitals NHS Foundation Trust, Newcastle upon Tyne, UK
The original article has been corrected.

Open Access This article is licensed under a Creative Commons Attribution-NonCommercial 4.0 International License, which permits any non-commercial use, sharing, adaptation, distribution and reproduction in any medium or format, as long as you give appropriate credit to the original author(s) and the source, provide a link to the Creative Commons licence, and indicate if changes were made. The images or other third party material in this article are included in the article's Creative Commons licence, unless indicated otherwise in a credit line to the material. If material is not included in the article's Creative Commons licence and your intended use is not permitted by statutory regulation or exceeds the permitted use, you will need to obtain permission directly from the copyright holder.To view a copy of this licence, visit http://creativecommons.org/licenses/by-nc/4.0/. 